\title{
Sustainable work in transition: Policy background, concepts and research arenas
}

\author{
Kenneth Abrahamsson
}

\section{Abstract}

The future of work is today discussed at global level in Agenda 2030 and SDG 8, by ILO and in the Global Deal, which is a multi-stakeholder initiative for social dialogue and inclusive growth. Future of work, social innovations and inclusive growth are also central policy missions for the OECD, the European Commission, and its agencies Cedefop, EU-OSHA and Eurofound. The European Pillar of Social Rights highlights the need for a European social model, promoting a progressive interplay between economic development, good working conditions and social protection. This article analyses concepts of quality of work, decent work, and sustainable work. Its title comprises different connotations of sustainable work in transition. Firstly, sustainable work has not received significant attention in the policy agenda on sustainable development. Secondly, new forms of work and the dissolution of the traditional workplace and standard employment relations call for a widened use of the content of sustainable work. Thirdly, the Green Deal, low carbon omissions and new energy systems will have substantial impacts on work organisation and production systems. Finally, digitalisation, labour market transformations and increasing job longevity make job shifts and skills upgrading more common, and sustainable work must be seen in a life-course and lifelong perspective.

Keywords: good work, job quality, employment relations, green deal, workplace innovations, the precariat, future of work

\section{Introductory comment on sustainable development}

The concept of sustainable development was launched by the Brundtland Commission in Report of the World Commission on Environment and Development: Our Common Future in 1988. The Commission focused on environmental sustainability: the survival of our planet, but also gave priority to social sustainability. In her foreword to Our Common Future, Gro Harlem 
Brundtland underlined the need for a new era of economic growth that is both socially and environmentally sustainable, as well as socially responsible. ${ }^{1}$

«Many critical survival issues are related to uneven development, poverty, and population growth. They all place unprecedented pressures on the planet's land, waters, forests, and other natural resources, not least in developing countries.»

The EU adopted its first Sustainable Development Strategy at the Gothenburg European Council in 2001. This was followed by the renewed Sustainable Development Strategy for the enlarged EU in June 2006. This defines sustainable development in the following terms: "Sustainable development means that the needs of the present generation should be met without compromising the ability of future generations to meet their own needs." The strategy's key objectives cover environmental protection, social equity and cohesion, prosperity and the EU's international obligations (European Council Document 10917/06).

It set out seven key challenges, with targets and policies to meet them, i.e., climate change, transport systems, sustainable consumption and production patterns, management of natural resources, public health equity, socially inclusive societies and quality of life and finally support for global sustainable development. Sustainable work and sustainable work systems were only mentioned indirectly in the EU Sustainable Development Strategy, but it is evident that health promotion and quality of life have central roles in the strategy.

In 2015, the United Nation launched the Sustainable Development Goals comprising 17 general goals and 169 sub-targets. SDG number 8 concerns decent work and economic growth. The SDGs also contain a strong social concern. ${ }^{2}$

«The Sustainable Development Goals (SDGs) aim to encourage sustained economic growth by achieving higher levels of productivity and through technological innovation. Promoting policies that encourage entrepreneurship and job creation are key to this, as are effective measures to eradicate forced labour, slavery and human trafficking. With these targets in mind, the goal is to achieve full and productive employment, and decent work, for all women and men by 2030. »

The purpose of Goal 8 Decent work and economic growth is to promote inclusive and sustainable economic growth, employment and decent work for all. The UN SDG's focus corresponds to ILO policies for decent work (UN SDG 8).

«Decent work means opportunities for everyone to get work that is productive and delivers a fair income, security in the workplace and social protection for families, better prospects for personal development and social integration. It is also

\footnotetext{
${ }^{1}$ https://sustainabledevelopment.un.org/content/documents/5987our-common-future.pdf.Downloaded 2021-01-31. Quote from chairwoman's foreword.

${ }^{2}$ https://www.sdgfund.org/goal-8-decent-work-and-economic-growth. Downloaded 2020-10-20
} 
important that all women and men are given equal opportunities in the workplace. A continued lack of decent work opportunities, insufficient investments and underconsumption lead to an erosion of the basic social contract underlying democratic societies: that all must share in progress. »

The Global Deal for decent work and inclusive growth was launched 2016 by Swedish Prime Minister Stefan Löfven as a concrete input to the UN 2030 Agenda for Sustainable Development. Its purpose is to bring together various stakeholders to promote joint solutions, while still representing their different interests. Effective social dialogue requires mutual respect and trust, to create favourable conditions for collaboration between employers, workers, and governments. ${ }^{3}$ This mission is now organised and managed in collaboration with the OECD.

In November 2017 the European Pillar of Social Rights was launched at an EU summit meeting in Gothenburg, Sweden. The vision of the pillar is to find a balance between economic development and growth, good working condition and social protection. ${ }^{4}$

«The aim of the European Pillar of Social Rights is to serve as a guide towards efficient employment and social outcomes when responding to current and future challenges which are directly aimed at fulfilling people's essential needs, and towards ensuring better enactment and implementation of social rights. »

The European Pillar focusses three policy dimensions concerning future of work in the EU. They are equal opportunities and access to the labour market, fair working conditions and social protection and inclusion. The European Pillar of Social Rights are related to some of the SDGs, but not all of them. SDG 8 Decent Work and Inclusive Growth directly shares the same field of action as EPSR. Of particular interest are also SDG 1 No poverty, SDG 3 Health and Well-being, SDG 4 Quality Education and SDG 5 Gender Equality, SDG 9 Industry, Innovation and infrastructure and SDG 10 Reduced inequalities and finally SDG 17 Partnership for the Goal. It constitutes a major challenge for policies, research and, direct actions to analyse the intersection between Sustainable Development Goals and the European Pillar of Social Rights. The vision of the pillar underlines quality of work, workplace innovations and employment security (EU 2017, p. 5).

«Innovative forms of work that ensure quality working conditions shall be fostered. Entrepreneurship and self-employment shall be encouraged. Occupational mobility shall be facilitated. »

«Employment relationships that lead to precarious working conditions shall be prevented, including by prohibiting abuse of atypical contracts. Any probation period should be of reasonable duration. »

\footnotetext{
${ }^{3}$ https://www.theglobaldeal.com/about/. Downloaded 2020-10-08

${ }^{4}$ https://ec.europa.eu/commission/sites/beta-political/files/social-summit-european-pillar-social-rights-booklet en.pdf. Downloaded 2010-10-15.
} 
The need for good and constructive partnerships is also highlighted, with special focus on the social dialogue and the role of social partners.

«Social dialogue plays a central role in reinforcing social rights and enhancing sustainable and inclusive growth. Social partners at all levels have a crucial role to play in pursuing and implementing the European Pillar of Social Rights, in accordance with their autonomy in negotiating and concluding agreements, and the right to collective bargaining and collective action. »

The concept of sustainable work has been developed over recent decades. It took several years, however, before workplace sustainability was adopted as a member of the sustainable development family. Hvid and Lund (2002) pointed early at the tension between environmental interests on the one hand, and labour markets and job protection interest on the other, by illustrating conflicts between the environmental movements and trade unions in the 1970s and 1980s. Today, social partners share a more positive view on the future of the Green Deal as a mission for Europe. ${ }^{5}$ Its main purpose is to make EU's economy sustainable, by meeting climate and environmental challenges with powerful policy missions to create new opportunities together with a just and inclusive transitions. The Green Deal calls for comprehensive and long-term policies, and is also a future mission of the European Social Dialogue.

In practice, however, there are examples of the tension between different goals, e.g., Greenpeace in summer 2020 was blocking tankers from delivering oil to the Preem refinery in Lysekil, north of Gothenburg. This conflict illuminates the tension between low-carbon policies, and business and job protection interests, in plans to expand the refinery, a goal conflict that is currently creating headaches at the governmental level in Sweden. The conflict was avoided when the company, for business reasons, decided to withdraw its expansion plans.

Thus, the dynamic policy concept of sustainability is embedded in several policy circles with the biosphere and global survival as the broadest perspective, followed by climate change and environmental challenges, as well as sustainable energy systems. Social sustainability comprises welfare systems, health and living conditions. In a labour market context, it is common to talk about sustainable workforce providing good conditions for job entrants, people at work, as well as individuals in the transition to retirement. The focus of this article is on sustainable work systems and sustainable work, i.e., work environment, occupational health and safety, gender equity and no discrimination, learning and development at work, workers co-determination and participation, control and influence, as well as productivity and growth.

\footnotetext{
${ }^{5}$ https://ec.europa.eu/info/strategy/priorities-2019-2024/european-green-deal en. Downloaded 2020-10-08.
} 


\section{In search for definitions of sustainable work}

The concept of sustainable work has been increasingly used in policy quarters and research over the last two decades. There are numerous definitions that sometimes overlap and in other contexts comprise a specific part of the concept. The Swedish Vinnova-supported Platform for Sustainable Work in Horizon 2020 used this broad definition: 6

«Sustainable work highlights the dynamic fit between employees and working conditions and is a generic policy concept. Sustainable work promotes health, wellbeing, learning and influence, as well as productivity, innovation and growth. The goal is to promote continual growth and regeneration of human, social, economic and ecological resources. The strategic importance of sustainable work, as a resource for health, innovation and growth, is emphasised in the European innovation strategy, and also by the social partners. Therefore, sustainable work needs to be a more visible and coherent theme in Horizon 2020. »

Docherty et al. (2009) highlighted a balanced development of various resources operating in a work system. Sustainability is primarily identified with ecological and environmental issues, nowadays quite often connected with climate crisis and the striving for a low-carbon society. They focused on human and social sustainability at work, but also point to human, social, economic and ecological dimensions where business goals, social goals and job quality come together. ${ }^{7}$

Sustainable work as a policy mission was launched in 2001 during the Swedish EU Presidency, and by research from the then National Working Life Institute, abolished in 2007. The principles of workplace sustainability are built on the following basic assumptions formulated by Docherty et al. $(2009$, p. 7$)$ and here presented in a shortened version:

- The opportunity to develop as a person, a professional and a member of a society through work experiences is a basic human right.

- The sustainability of human and social resources is one of the foundations of economic sustainability.

- Sustainability at work is one of the foundations for social development and sustainability of whole societies

- Sustainability of human and social resources is needed to secure ecological sustainability, "because only people and groups who operate sustainably are able to grasp, prioritise, and work toward ecological sustainability.

Eurofound has inspired the European discourse on job qualities and has chosen to highlight a life-course perspective on sustainable work (Eurofound 2015a, p.2).

\footnotetext{
${ }^{6}$ http://sustainablework2020.se/. Downloaded 2020-10-15.

${ }^{7}$ Docherty et al. (2009) Creating Sustainable Work Systems. Developing social sustainability and Docherty in Håkansta, C.\& Abrahamsson, K. (eds.) (2008) Workplaces of the Future. Work-In-Net Foresight Seminar held in Stockholm, Sweden.
} 
«Eurofound's working definition of 'sustainable work over the life course' means that working and living conditions are such that they support people in engaging and remaining in work throughout an extended working life. These conditions enable a fit between work and the characteristics or circumstances of the individual throughout their changing life, and they must be developed through policies and practices at work and outside of work. »

The life-course perspective on sustainable work differs from an age-management perspective, focusing on adjusted workplaces for older workers. In a lifespan and job longevity approach, work environment for young workers could have negative impact on working conditions in middle-age or for older worker. High levels of job strain, physical requirements, noise and vibrations for young employees could have health repercussions later in life, and could shorten the occupational career.

Eurofound (2014) also launched the concept of sustainable work as a core concept in its previous work programme.8 Sustainable work is, according to Eurofound, a polysemic concept used in various contexts and social levels (Eurofound 2014, p.1):

- Individuals: capacity to perform a specific job and to remain on the labour market over the life course

- Organisations: companies' potential to develop efficient work organisations; ensuring both physical and mental wellbeing of the workforce and ensuring up to date adequate skills.

- Society: favouring inclusion on the labour market, increasing social cohesion, helping to reduce the drop-out and poverty rates.

Eurofound highlights three dimensions of sustainability, namely sustainability and ageing, sustainability over the life course and finally, sustainable work systems. The third mission emanates from the thinking of Docherty and his colleagues, by highlighting ting that human and social resources should not just be consumed, but also being preserved and regenerated and to allow them to grow and develop. Learning and development play a central role in this context (Foundation Seminar Series, 2014, p.7):

«Learning is a key components of sustainable work systems, and must take place at all levels: individual, collective and organisational and beyond that among organisations in networks, coalitions and systems. Learning is key to support change. Instruments to contribute to it are development of vision within the organisation, participation in decision making of all stakeholders, development of partnerships and coalitions to stimulate dialogue, developing networks for collective learning from pooling experiences, reflective learning is important. Sustainability is a dynamic learning-oriented state. »

\footnotetext{
${ }^{8}$ See Foundation Seminar Series 2014. Sustainable work through the life-course. Background paper. http://www.eurofound.europa.eu/events/2014/fssdublin/index.htm
} 
The promotion of green carbon-free jobs and production systems is bridging the gap between the global sustainability movement for ecological survival, and the focus on sustainable work systems. When the ILO (2013) is promoting sustainability, green jobs are at the centre of the policy mission. ${ }^{9}$

«This report addresses two of the defining challenges of the twenty-first century: achieving environmental sustainability and turning the vision of decent work for all into a reality. It shows that not only are both challenges urgent, but they are also intimately linked and will have to be addressed together. While it is certain that environmental degradation and climate change will increasingly require enterprises and labour markets to react and adjust, the goal of environmentally sustainable economies will not be attained without the active contribution of the world of work. »

Decent and sustainable work has to be seen in a social, economic and ecological context, where the different levels and subsystems interact with each other, and also illuminate various challenges and goal conflicts.

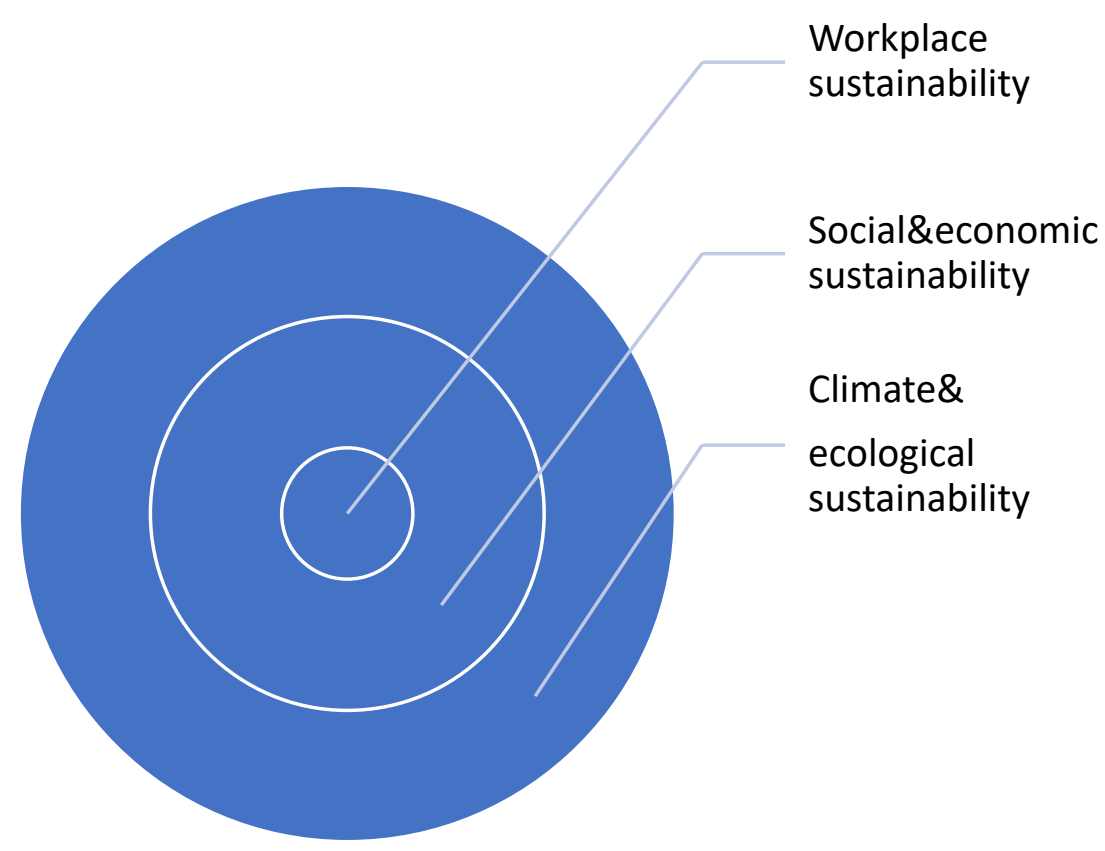

Figure 1: Levels of sustainability

\footnotetext{
${ }^{9}$ Sustainable development, decent work and green jobs, ILO 2013; page xi
} 


\section{Crossing the scientific boundaries of sustainable work}

Policy development and research on working life and work organisations reflect a growing conceptual diversity. The concepts of good working conditions should, more and more, be replaced by sustainable work or sustainable work systems. The notion of workplace innovations has been in operation during the last two decades. The model of lean production tends to be used more and more in industry and in the public service sector. Digital Taylorism is another buzz-phrase, focussing on new patterns of division of labour in a polarised and segregated labour market. Flexible employment conditions for better or worse are covered by the concept of precarious work (Standing, 2011). The metaphor "work without boundaries" implies a dualism in flexibility; empowerment and flexibility from the employee's perspective or substitution flexibility as seen from employers' the production system perspective (Allvin et al., 2011).

One of many challenges in this context is to bridge the gap between sustainable work and the notion of workplace innovations. Sustainable working life, or sustainable work systems, are so far open concepts that need further specification. Common policy concepts in Sweden have been "good work" or "developing work", while the concepts of sustainable work and healthy workplaces are now being used more often. Thus, sustainable work has more and more been used in addition to social and environmental sustainability; and they all have high policy popularity both among agencies, social partners and other actors. Some international efforts have been made, however, to clarify the concepts (Fischer \& Zink, 2012; Zink, 2014; Kira \& Eijnatten, 2011). Eijnatten defines the concept in the following way (quoted from Fischer \& Zink, 2012, p. 3904):

«A Sustainable Work System is a work system in which the quality of work (i.e., employee's health, well-being, and personal development); the quality of the organisation (productivity, efficiency, the ability to meet the challenges of tomorrow's business); and the quality of connections with the environment (both nature and society) are constantly kept at the same high levels. Sustainable Work Systems should reproduce resources [...] [t] hey develop by growth in the amount of resources in a reproduction cycle. »

The illustration below highlights the scientific borders between various fields of research that have importance for sustainable work. The focus in this article is on occupational health and safety, on demand-control/stress and learning options, as well as productivity and value creation. Other relevant fields are employment relations/flexibility and boundaryless work including precarious working conditions, new technology, ICT and design, and new forms of work and management as well as leadership. 


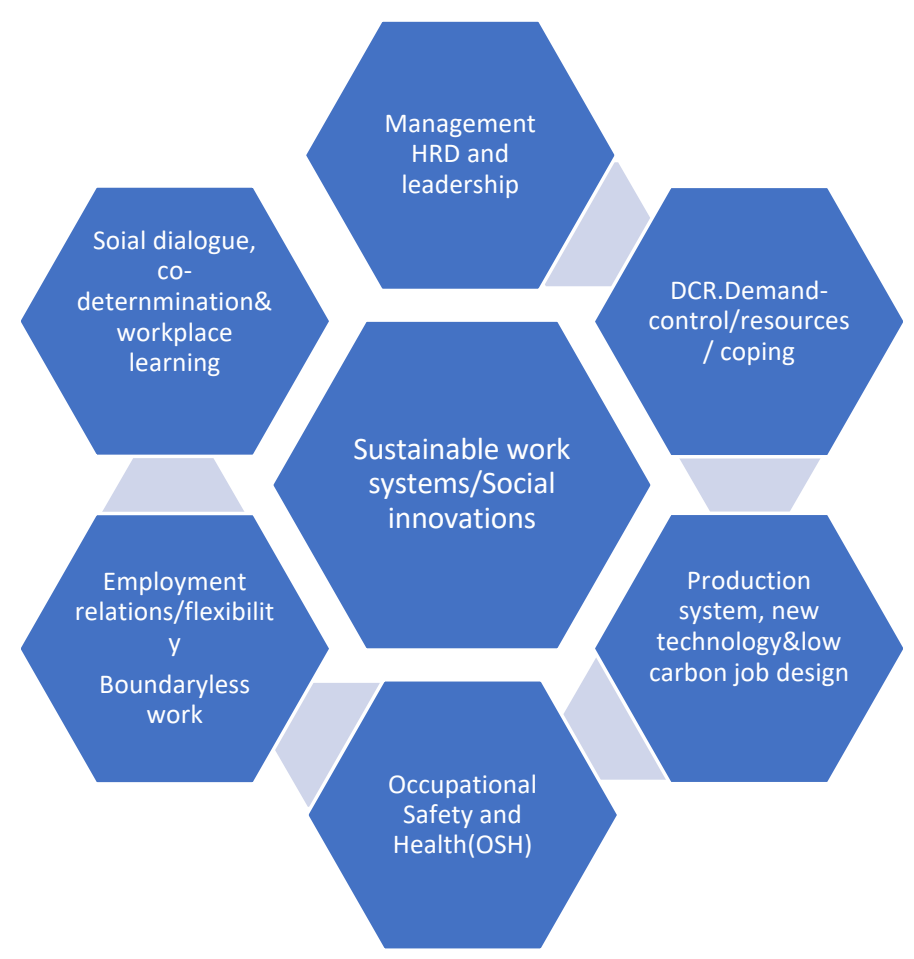

\section{Figure 2. Intrinsic and external factors for sustainable work}

The implementation of policies for sustainable work systems is not, however, an easy task. Fischer and Zink (2012) elaborate objectives and institutional barriers when you want to use human, social and natural capital, and at the same time consider personnel subsystems, technical subsystems, as well as the organisational and management structure. They underline the importance of sustainable work systems, but also express some doubts on how all objectives and conflicting goals from various interests could be solved in specific work contexts (Fischer \& Zink, 2012, pp. 3904-3905):

«In praxis, striving for "real" sustainability often is a hard job as systemic thinking in long-term and complex interdependencies is just not in the human nature. Besides this, all organisations, work systems as well as individuals only have limited resources to cope with the "daily business" and to meet the needs of their relevant stakeholders.»

Sustainable work and sustainable work systems are complex processes existing in organisational, technological, economic and management contexts, aiming at good, healthy and productive outcomes. Flexibility, boundaryless work and social dialogue make it difficult to design a specific and static sustainable work system. Sustainable work is striving for an optimal balance between social and workplace sustainability on one hand, and corporate goals for environmental sustainability, productivity and growth on the other. Sustainable work needs to be a high priority subject for negotiations between social partners, to set together a sustainable work deal, or collective agreements aiming for higher workplace sustainability. Another challenge is to catch a functional definition of green jobs. 


\section{The two faces of the good work metaphor}

The Swedish discussion of Good Work, launched by the Metal Workers Federation during the 1980s and onwards focused on healthy workplaces, the interaction between work, education and learning, as well as the social support needed to create good working conditions both for men and women. Good Work as an infrastructure for work, welfare and life quality was presented by the Swedish Metal Workers Federation in a report from 1985, which comprised the following elements:

1. Job security

2. Equal and fair share of production results

3. Workers' co-determination

4. Collaborative work organisation

5. Skills and competence development at all levels

6. Continuing education/ lifelong learning

7. Flexible and employee-friendly working hours

8. Workplace equality and social inclusion

9. A healthy and risk-reducing work environment

The Swedish Trade Union Federation, LO, decided in its congress 2016 to initiate a new policy agenda on Good work in our times to be presented in 2020. One of the motions on good work at the 2016 congress focused on power relations at work. Good work is the labour movement's vision that power, participation and responsibility should be shared between the workers and the companies. Today's concentration of power leads to undemocratic decisions, an oppressed working class, mismanagement with resources and exhausted workers. The new LO Good Work project is an on-line dialogue with its unions and takes the form of webinars, research overviews, and focussed activities on union and workplace level. Due to the pandemic, the 2020 LO convention was held on the net, and the discussion of the good work concepts was postponed. $^{10}$

It is interesting to make a distinction between good work as healthy and developing working conditions, and good work as a contribution to society, or a professional skill in a certain field of industry or public services. The latter view is reflected by Howard Gardner, Mihaly Csikszentmihaly and William Damon (2001) in the book Good work. When Excellence and Ethics Meet. ${ }^{11}$ Good work in this connotation does not only comprise skills and competencies, but also professional ethics: a mental orientation that you contribute to good deeds.

«People who do good work, in our sense of the term, are clearly skilled in one or more professional realms. At the same time, rather than merely following money or fame alone, or choosing the path of least resistance when in conflict, they are thoughtful about their responsibilities and the implications of their work. »

\footnotetext{
${ }^{10}$ https://www.lo.se/start/material/kongressprotokoll 2016 del 1. Downloaded 201015

${ }^{11}$ Howard Gardner, Mihaly Csikszentmihaly and William Damon (2001) Good work. When Excellence and Ethics Meet. New York: Basic Books.
} 
Work ethics and reflective production are aspects that can be related to sustainable work and sustainable work systems. Sustainable work also, according to Hvid and Lund (2002) entails actions of reflection, but is also embedded in a structure of power. They argued that sustainable work has to be built on reflexive management characterised by high degrees of autonomy in production, in democracy and decision making, and value creation through an open dialogue.

\section{Conceptual framework for quality of work}

Working realities differ between countries, in various types of jobs and for different groups. Preventive initiatives in occupational health have roots in the late 19th century. Standards were not set to reach the highest levels of good work, but to avoid the most dangerous workplaces, to counteract risks and fatal injuries, to hinder dangerous exposure of chemicals, noise and too heavy tasks. Good work, in a historic sense, tends to start from the bottomline, and define what is not acceptable and humane. Early legislation also focused on childlabour and women's nightwork.

Today, there are many concepts or models to describe job qualities. One strand is to look at attractive jobs from a life-course perspective, i.e., attractive jobs for young people or work ability and healthy for older workers. Gardner et al. (2001) have illuminated good work as good deeds, productive contribution or what in Sweden is labelled as "ett gott dagsverke": a good day of work. Biggs (2017) follows the Studs Terkel (1996) tradition of shaping the life and character of various occupations and work communities. "We may love our work, hate our work, find meaning in our work or none, but it's what we do all day long, and it shapes us." (Biggs, 2017, p.11) A common model is to describe good or bad jobs is the DemandControl, DC model and its focus on job strain, control and stress (Theorell \& Karasek, 1996). The DC model has been broadened to Demand Control, Resource model, the DCR model. They have inspired various streams on research on occupational health and safety in a work organisation perspective. Karasek (2017) discusses another variation of the model as the ADC model or the Associationalist Demand Control model, by including a wider societal context.

Work and identity are reflected in the concept of coherence and meaning of work promoted by Antonovsky (1996). Work communities and the social context of work are investigated and conceptualised in many different research approaches, e.g., work as communities of practice (Wenger, 1998), working cultures (Terkel, 1997) or workers' collective by Lysgaard (Axelsson et al., 2019) Paid and unpaid work: gender challenge and issues of work life balance is a field with increasing interest during last decades. Another metaphor is healthy corporations and healthy workplaces. High road workplaces (Parent-Thirion et al., 2017) in knowledge intensive and technology dominated environment is another sector of the field of good workplaces. Finally, we can once more point to the concept of sustainable work systems. 
Eurofound and ILO (2019) share a definition of job quality in their joint report Working conditions in a global perspective (Eurofound and ILO 2019, p.1). ${ }^{12}$

«ob quality is increasingly recognised as a major policy concern. It is central to the ILO's Decent Work Agenda and to the European Union's Quality of Work policies. For workers, for the enterprises and organisations that employ them, and for societies, there are benefits associated with high-quality jobs, and costs associated with poorquality jobs. »

The EU conception of good work and inclusive work environments also focused on the mission of job-creation and diversity in working life. ${ }^{13}$

«Regaining full employment not only involves focusing on more jobs, but also on better jobs. Increased efforts should be made to promote a good working environment for all including equal opportunities for the disabled, gender equality, good and flexible work organisation permitting better reconciliation of working and personal life, lifelong learning, health and safety at work, employee involvement and diversity in working life. »

Job quality can be assessed in various ways. In policies and in public debate it is common to talk about good jobs and bad jobs (Green, 2006). But what is a good job and what constitutes good work? The report Indicators of Job Quality in the European Union (2009) published by the European Parliament, underlines that job quality is a multidimensional concept that can be approached with different methods and various theoretical approaches. That report was launched when the slogan "more and better jobs" was an integral part of the European Employment Strategy and the Lisbon Strategy. It was also presented at a time when policy attention to good jobs indicators was at a higher level. There is no one single way to understand and measure job quality.

The multidimensional nature of job quality makes the development of a single indicator or a system of indicators more difficult as, prior to such development, it is necessary to define what aspects should be taken into consideration and their overall impact on job quality. Job quality can be approached in three ways according to the report. The first method is to look at job satisfaction as "an overall indicator of job quality". The second approach is to ask workers what makes a good job, and finally defining job quality from theories and models of social and medical sciences. Focus on job satisfaction is a direct and useful method in regional or national contexts, but has major weaknesses in international comparative studies, where there tend to be significant gaps between "subjective" and "objective" indicators. The second

\footnotetext{
${ }^{12}$ https://www.eurofound.europa.eu/sites/default/files/ef_publication/field_ef_document/ef18066en.pdf Eurofound and International Labour Organization (2019), Working conditions in a global perspective, Publications Office of the European Union, Luxembourg, and International Labour Organization, Geneva. Downloaded 2021-02-01

${ }^{13}$ European council ( 2001). Presidency conclusions. Stockholm meeting 23 and 24 March 2001.par. 26. Source: https://www.consilium.europa.eu/ueDocs/cms Data/docs/pressData/en/ec/00100-r1.\%20ann-r1.en1.html. Downloaded 2021-02-01.
} 
method has both advantages and drawbacks. To listen to workers' voice about good jobs is part of active participation in the development of better working conditions. A challenge or a problem is to specify which dimensions should be used for expressing ideas or visions of good jobs, which also make international comparisons more difficult.

The third way comprises a number of scientific roads. Economists and sometime sociologists could use wages and labour compensation as an indicator of good jobs. Sociologists, psychologists and political scientists, as well as scholars from management science, could look at power relations and industrial democracy, and also participatory options. Traditional sociologist might look at alienation as a negative dimension of job quality, but might nowadays be more focussed towards skills, forms of autonomy or powerlessness. A more institutional approach from sociology, psychology and industrial relations can highlight issues in employment relations, precarious work or forms of skills development and career progression. Job quality can also be looked at from an occupational health and safety perspective looking at physical and psychosocial risks, injuries, illness and absenteeism. Finally, work-life balance studies could result in working time patterns, boundaries to private life, workload and stress. To sum up: job quality is a complex and multidimensional phenomenon. More broadly, the report (EU 2009) makes a distinction between work quality, job quality, and employment quality.

The OECD has developed a framework to measure the quality of jobs, with reference to three objective dimensions. They constitute, according to OECD "a comprehensive assessment of job quality. ${ }^{14}$ This model differs from the labelling of job quality, work quality and employment quality.

- Earnings quality captures the extent to which earnings contribute to workers' wellbeing in terms of average earnings and their distribution across the workforce.

- Labour market security captures those aspects of economic security related to the risks of job loss and its economic cost for workers. It is defined by the risks of unemployment and benefits received in case of unemployment.

- Quality of the working environment captures non-economic aspects of jobs including the nature and content of the work performed, working-time arrangements and workplace relationships. These are measured as incidence of job strain characterised as high job demands with low job resources.

No attempt is done to bring the three dimensions together in a common index (Cazes et al., 2016, pp. 19-20). ${ }^{15}$

\footnotetext{
${ }^{14}$ http://www.oecd.org/statistics/job-quality.htm and http://www.oecd.org/sdd/labour-stats/Job-quality-OECD.pdf

${ }^{15}$ https://www.oecd-ilibrary.org/social-issues-migration-health/measuring-and-assessing-job-quality_5jrp02kjw1 mr-en
} 
«Earnings quality, labour market security, and quality of the working environment are three complementary dimensions of job quality. They should be considered simultaneously, together with the number of jobs that exist (i.e., job quantity), when assessing labour market performance, well-being and the role of policies and institutions. These dimensions are broad enough to encompass the most significant aspects of job quality that shape workers' well-being. No attempt is made at this stage to aggregate them into a single indicator of job quality. Linking them together is not conceptually straightforward. »

Job quality is, however, not a static phenomenon. The Eurofound \& ILO (2019) report on working conditions in a global perspective has a positive view on improving job quality (Eurofound \& ILO, 2019, p.2). ${ }^{16}$

«ob quality can be improved by reducing excessive demands on workers and limiting their exposure to risks: and also by increasing their access to work resources that help in achieving work goals or mitigate the effects of these demands. Each dimension of job quality can also be improved through workplace practices and policies. »

And furthermore, the report highlights the positive and dynamic functions of job quality (Eurofound and ILO 2019, p.11).

«Many job quality features that are beneficial for workers are supportive of a positive and fulfilling quality of working life. Thus, high(er) levels of job quality are associated with health and well-being, work-life balance, financial security and skills development (Eurofound, 2016). Statistical analyses included in all national reports confirm these findings. »

\section{Workplace innovations and sustainable work: similar and different}

Workplace innovation has received growing attention and interest both in research and European policy formation. A valuable overview of this development has been presented by Oeij, Rus \& Pot (2017) in the book Workplace Innovation. Theory, Research and Practice. It aims to clarify concepts, theories, models, experimenting and policy development. It also reflects shifting European policies from DG Employment and DG Grow. Furthermore, it contributes to clarifications of the concept and applications of WPI in a theoretical context. Another relevant and relatively recent book in this context is Helge Hvid and Eivind Falkum's (2018) book Work and Wellbeing in the Nordic Countries. Critical perspectives on the world's best working life. It has a stronger focus on the role of social partners, NPM in reforming and de-forming

\footnotetext{
${ }^{16}$ https://www.ilo.org/wcmsp5/groups/public/---dgreports/---dcomm/---publ/documents/publication/wcms 696174.pdf. Downloaded 2020-09-26.
} 
various professions and precarious work. The focus is mainly on Denmark and Norway. There might not be a Nordic Model: more Nordic approaches, as there is no European model, but various labour market regimes and working life patterns.

Sustainable work and workplace innovations are conceptual siblings with an overlapping DNA-structure. Sustainable work belongs to the larger family of job quality, which can be divided into job quality, work quality and employment quality. Thus, sustainable work reflects the goals and visions of good work and a healthy and safe work environment, while workplace innovation strives for a productive balance between organisational determinants and development on the one hand and good and healthy working conditions on the other. With some simplification, one might say that sustainable work, so far has a stronger focus on job quality and work environment over a life-course, while workplace innovation is stronger allied with work organisation research and innovative forms of work. An innovative workorganisation does not by definition become healthy and beneficial for the worker i.e., the theoretical discourse on the uberisation of work, and negative impact of platform work, could be good examples (Warhurst, Mathieu \& Wright, 2017).

DG Grow presents a broader definition of workplace innovations covering various dimensions and levels of enterprises, economy and labour market. ${ }^{17}$

«To stay at the competitive edge, companies need to invest not only in technological innovation but also in non-technological practices. Workplace innovation can mean many things such as a change in business structure, human resources management, relationships with clients and suppliers, or in the work environment itself. It improves motivation and working conditions for employees, which leads to increased labour productivity, innovation capability, market resilience and overall business competitiveness. All enterprises, no matter their size, can benefit from workplace innovation. »

The concept of workplace innovation exists in a cluster of ideas, models and driving forces. The approach represented by the EUWIN community underlines the role of employeesupported workplace innovations that also highlights the role of social partners and the workplace dialogues as a method (Alasoini et al., 2017). In the efforts to find a working definition, Oeij and Dhondt (2017) take an integral approach highlighting the combined role of improved organisational performance and quality of working life. Furthermore, they stress the interactive and participatory role for employees in the process and highlight four elements of a WPI model:

- Structural aspects (e.g., organisational design)

- Cultural aspects (e.g., leadership, coordination and organisational behaviour)

- Improve performance (e.g., productivity, innovation and quality)

\footnotetext{
${ }^{17}$ https://ec.europa.eu/growth/industry/policy/innovation/workplace_en. Downloaded 2020-09-19.
} 
- Quality of work (e.g., wellbeing at work, competence development, employee engagement)

Thus, the WPI approach is not seen as a goal in itself but has an integral function to promote a healthy and productive workplace in an organisational climate of supporting employees, employers, stakeholders and customers. The impact of WPI should, according to Oeij and Dhondt (2017, p.76), be reflected in three types of outcomes: "organisational performance, quality of working life, and innovative capabilities of firms and innovative abilities of people." Powerful top-down management and regulations are neither sufficient nor effective to improve job quality and create a good work environment. "Framework agreements between the social partners and preferably governments as well are probably more successful. Such agreements could also be connected with national, sectoral or local workplace innovation initiatives." (Pot et al., 2017, p. 107).

Workplace innovations can be seen in relation to enterprise size and corporate structure. The conditions for large enterprises with standardised management models might differ from SMEs with a bigger variation in ways of organising work and productive systems. The OECD has recently looked at regional and national variations in learning patterns in SMEs in different countries (Lorenz \& Potter, 2019). They found that shares of learning organisation and discretionary learning SMEs were greater in Nordic countries where learning organisation SMES represent approximately $70 \%$ of SMEs in Sweden and Finland, and more than $40 \%$ in Denmark. It was lower in many eastern European countries, as well as in Italy, Turkey and Portugal. More generally, there are higher shares of learning organisations and discretionary work in knowledge-intensive business than in manufacturing, construction and transport sectors. It seems reasonable to say that learning organisations and discretionary work are prerequisites in workplace innovations, but they also play an important role in other models. $^{18}$

\section{From standard employment to atypical and precarious jobs}

Employment relations have a strong impact on work environment and workers' health. When Guy Standing (2011) presented his study The precariat. A new and dangerous class, he also highlighted the dynamic relations between employment relations and quality of work. Traditionally, research into OSH-dimensions and quality of work analysed working conditions in large enterprises, or SMEs with employees following the pattern of standard employment.

Today, both standard employment relations and the workplace are much more flexible. Modern working life can increasingly be described as Work without boundaries (Allvin et al.,

\footnotetext{
${ }^{18}$ Lorenz, E. \& Potter J. (2019). "Workplace organisation and innovation in small and medium-sized enterprises", OECD SME and Entrepreneurship Papers, No. 17, OECD Publishing, Paris, https://doi.org/10.1787/11732c0c-en.
} 
2011). There are various ways and categories to describe jobs with or without employment relations. On each end of the scale, you have standard employment and unemployment. Between these categories exist temporary and precarious jobs, portfolio jobs and selfemployment.

Eurofound (2015b) has identified a number of new forms of work, in which employment relations tend to be more complex; employee sharing, job sharing, interim management, casual work, ICT-based mobile work, portfolio work, crowd employment and collaborative employment. Many of these forms of work are not connected with traditional employment relations, but represent various forms for an employer to hire competence or skills for specific task. Precarious jobs have more often been connected to gainfully wage-earner with insecure employment relations, having temporary jobs are being made redundant. Precarious jobs, however, are also relevant for many self-employed persons, especially for unvoluntary selfemployment or acting on a labour market where self-employment almost is a rule. Eurostat (2018) reports that self-employment could vary between six to eight percent in in Norway, Denmark, and Sweden up to 30 percent in Greece. Individuals being account-owners in small firms are often more vulnerable than individual being employed, and can rely on labour laws, social protection, and sometimes union rights (Conen \& Schippers, 2020).

The focus of Standing (2011) is more the social category of the precariat as a new class on the labour market. The precariat is, however, very heterogenous, and the concept has different connotations various countries as working poor, being forced into more unsafe employment relations, belonging to a group of temporary or seasonal workers, or older workers on a post-work mission to add a low pension. Standing argues that there is a relation between precarious work and citizen rights, and workers in the precariat might be labelled as denizens or second- class citizens in the Athenian democracy. Precarious work can also comprise high levels jobs in the cultural sector as well as various form of portfolio consultant jobs. Kalleberg \& Vallas (2017) define precarious work as "work that is uncertain, unstable and insecure, and in which employees bear the risks of work (as opposed to businesses or the government) and receive limited social benefits and statutory entitlements (Kalleberg \& Vallas, 2017, p. 1).

Rodgers (1989), also in Cohen \& Shippers (2020), has identified four dimensions of precariousness; income adequacy for a decent standard of living, social protection by unions or the law, degree of certainty in long term employment conditions, and influence and control over the labour process. An additional dimension of precarious working conditions is the factor of multiple job holders. The insecurity aspect also implies subjective feelings of risks of being redundant, or not keeping a more continuous relation to a certain employer. There is also a relation between precarious work, work related injury and the risks of receiving a disability pension (Ojala \& Pyröriä, 2019). In the light of the European Pillar of Social Rights, good provision of social protection is a necessity for individuals being caught by precarious jobs. More generally, there is an interplay between precarious jobs, households and social gradients, and forms of social protection by the welfare state. 
There are also relations between precarious work and social conditions, and labour market position and social conditions of individuals are important health determinants (Van Aerden et al., 2017). A study in the US from 1995 - 2017 showed that women, and especially women with children, are overrepresented in precarious jobs in comparison with men (Albelda et al., 2020). A study of a Canadian population showed that immigrants: both males and females, more commonly work in-voluntary part-time work (Hira-Friesen, 2018).

A recent Swedish review on research of future work environment and employment relations pointed to the dynamic relation between forms of employment relations and quality of work (Sawee, 2020).

«The significance of employment types for health and safety has gained increased attention in recent decades, both in research and among official bodies and international organizations. The primary reason is likely that both in Sweden and internationally, there is a lasting trend towards an increase in employment types that deviate from traditional, standard employment and these new kinds of employment are associated with an increased risk of illness, lack of work-life balance and a weak social safety net. »

The dissolution of employment relations in the gig-economy, with its direct connection between customer and producer, could have negative repercussions on income, work environment and social protection. In agencies taking care of self-employed persons administration and economic service, it could be complicated also for persons trained in labour law to define who is an employer, and who is an employee.

More generally, the standard employment form is still the majority for wage earners in Europe; even so there is a variation between North and South and East and West. In this majority of standard employment individuals, a minority go to the same office, fabric or service centre and work from eight to five each day. Work without boundaries is more distributed in place, in time and in functions. This development has been heavily accelerated during the Covid-19 pandemic, where remote work in the office sector tends to be more the rule than the exception.

\section{Good jobs, bad jobs, or new jobs? Concluding remarks on future of sustainable work}

What do we know then about future studies in the field of working life? In a Swedish study Bergman et al. (2010) reviewed some prominent writings on the future of work in recent decades. Their conclusions were that the meaning and dignity of work permeate many studies, but that there is a lack of basic perspectives on class and gender. In addition, they 
point out that surprisingly few studies contain concrete predictions. Many studies have a normative approach, and they tend to highlight the desirable before the possible.

Job quality, employment conditions and skills requirements are significant dimensions of the European workplace. Are European jobs good or bad in an international comparative sense? It is, of course, not possible to give a clear and evidence-based response to such a broad question. One hypothesis could be that there are larger variations in job quality between Europe, and some other continents or countries with insufficient job protection, restricted or forbidden unions. lower wage and worse work environment. That does not mean that Europe can be characterised by good work, employee-friendly employment conditions and high wages. We know that there is strong inter-European variation in job quality, employment conditions and wages. The other side of the good job coin is a bad job. The visions of decent jobs, good jobs or sustainable work are more frequently used in policies, in programme documents for unions, social partners and governments. Bad jobs on the other side are also used in politics and unions, but may be more often by scholars from sociology, occupational medicine or organisational psychology, and also in comparative studies within or between countries based on various types of indicators.

The book Are bad jobs inevitable? Trends, Determinants and Responses to Job Quality in the Twenty-First Century (Warhurst et al., 2012) highlights driving forces and institutional mechanisms behind bad jobs and opportunities of good jobs in an international context. The introductory chapter raises seven major questions on good and bad jobs' discourse in the form of scenarios. The first scenario Jobs are getting better reflects the idea of upward convergence. Its opposite side is labelled in the second scenario Jobs are getting worse in line with Braverman's (1974) argument on degradation of work. Increasing stress and job strain at work, falling occupational health or more precarious jobs and uncertain employment conditions are taking that direction.

The third scenario focuses on the Polarisation of Job quality, a perspective being subject to an in-depth discussion among scholars on various ways to assess job quality, e.g., wages, working hours, employment conditions or job security. Scenarios four and five are illustrations of the polarisation idea and comprise Good jobs are getting better and Bad jobs are getting worse, a development often signified by growing income gaps. Finally, the authors presented a twisted development in scenarios six and seven where Good jobs go bad and Bad jobs are getting better. These seven scenarios illuminate the complexity in the development of job qualities in countries and regions with various labour market regimes and different institutional context, different positions of social partners.

So, what about new jobs? In recent years the discussion on job destruction, job creation or job retention has been quite hot, and shifted character when analyses and studies were deepened (Frey \& Osborne, 2013). From the alarming signals that half of current jobs would be abolished or lost in cyberspace within the next two decades, due to digitalisation and technological disruption, today's predictions move in an interval between six or twelve 
percent depending on type of work organisation, skill levels of the workforce and the number of low qualified jobs (Arntz et al., 2016). One possible development is that the gig economy and digitalisation can increase polarisation between good and bad jobs. The shifting character of the standard employment model to new employment contracts, increasing levels of temporary jobs, or patterns of self-employment, bogus self-employment included, will also contribute to shape the job quality of new jobs.

The European Agency for Safety and Health at Work (2018) published the future study on OSH risks and hazards Foresight on new and emerging occupational safety and health risks associated with digitalisation by 2025 European Risk Observatory Report two years ago. It was before the Covid-19 pandemic, and some of the risks might have been accelerated, due to the current threats to public and occupational health. The objective of the foresight project was to help to:

- have a better understanding of longer-term developments that could affect workers and how these may result from current policy decisions.

- consider priorities for OSH research, and actions that would prevent the occurrence of the possible new and emerging risks identified or minimise their possible negative impact in the future.

The rapid digital transformation of the world of work has fundamental impact on organisation of work and working conditions (European Agency for Safety and Health at Work, 2017, p.6). ${ }^{19}$

«The emergence of new technologies, such as the IOT, Al, big data, cloud computing, collaborative robotics, AR, additive manufacturing and online platforms, has a profound impact on the world of work. Although the spread and prevalence of the application of ICT-ETs are currently varied across Europe and across different sectors and socio-economic groups, ICT is becoming an integral part of nearly all sectors, rather than a sector of its own. »

The future study comprised four scenarios on new and emerging OSH challenges relating to how ICT-ETs could change automated systems and work equipment and tools used. They should also focus on how work is organised and managed in forms of business models, hierarchies, and relationships. Finally, attention should be paid to the characteristics of the workforce, responsibilities for managing $\mathrm{OSH}$, and the skills, knowledge and information required to work. The scenarios focussed on variations of governance and economic growth and were labelled evolution, transformation, fragmentation, and exploitation.

The report listed a number of new hazards or fields which needed more interest in the near future, such as: the potential for automation to remove humans from hazardous environments, but also to introduce new risks, particularly influenced by the transparency of

\footnotetext{
${ }^{19}$ https://osha.europa.eu/en/publications/foresight-new-and-emerging-occupational-safety-and-health-risks-associated. Downloaded 2020-10-08.
} 
the underlying algorithms, and by human machine interfaces. Another field was psychosocial and organisational factors that will become increasingly more important, because ICTETs can drive changes in the types of work available; the pace of work; how, where and when it is done; and how it is managed and overseen. EU-OSHA also highlighted increasing workrelated stress, particularly as a result of the impact of increased worker monitoring made possible by advances in and the increasing ubiquity of wearable ICT-ETs. Blurred boundaries between work and private life, 24/7 availability, and the online platform economy were also determinants influencing healthy working conditions.

The dissolution of the traditional workplace, with increasing ergonomic risks due to the increase in online working, and the use of mobile devices in non-office environments, was also mentioned in the study. Many aspects of cyber work and cyber risks, privacy and integrity, the algorithmic management of work and workers, Al, monitoring technologies and loss of control were also included workers lacking the necessary skills to be able to use ICT-ETs, cope with change and manage their work-life balance. Increasing job longevity, more frequent job changes growing numbers of self-employment have also to be considered looking ahead. Finally, the crossing border between public and occupation health was mentioned by the increase of sedentary work, a risk associated with obesity and non-communicable diseases, such as cardiovascular diseases and diabetes.

A more recent policy study on scenarios of the future of work from an occupational risk and health hazard perspective has been published by NIOSH (2020). It is also looking into new forms of work, the role of Al and Industry4.0 in new digital context of work (NIOSH, 2020, p. 1). 20

«Technology was identified as the primary driver of the future of work in most scenarios, and there were divergent views in the literature as to whether technology will create more or fewer jobs than it displaces. Workforce demographics, globalization, climate change, economic conditions, and urbanisation were also mentioned as influential factors. Other important themes included human enhancement, social isolation, loneliness, worker monitoring, advanced manufacturing, hazardous exposures, sustainability, biotechnology, and synthetic biology. »

This review comprises peer-reviewed literature, work scenarios from the grey literature, and themes in published literature. The first strand identified four fields of knowledge to be looked at in the future working life. The four scenarios which could overlap, were: (i) changing patterns of employment and work organisation, (ii) management of technological change and human-robot interaction, (iii) OSH challenges, and (iv) ethical issues. Driving forces for these scenarios are mega-trends like technology, demographics, globalisation and urbanisation. New and more automated industries and factory systems "cause a qualitative knowledge

\footnotetext{
${ }^{20} \mathrm{NIOSH}$ (2020) Potential Scenarios and Hazards in the Work of the Future: A Systematic Review of the Peer-Reviewed and
} Grey Literatures. 
transformation-from bodily and tacit into more theoretical and abstract knowledge and skills and from craftsman-like qualifications to more technical qualifications" (NIOSH, 2020). Other hazards of technology-based scenarios comprise changing employment patterns, precarious work, unemployment and underemployment, obsolescence of competency, as well as stress and work intensification.

Human-and-machine interaction in times of technological disruptions is discussed both in terms of job loss or attitudes, anxiety, and uncertainty of working with new technologies. Other risks in the field of occupational health and safety concern mental overload, work intensification, skills and jobs mismatch, but also issues of privacy, integrity and control. The review also highlights new ethical concerns in a more globalised and technology-driven world of work. The grey literature focuses more on the meso-level, by looking at business models, labour market change, social values, and the shift from manual to cognitive work. The third category, supplemental literature, is often built on common narratives of various types of work, and employment conditions which are extrapolated into future scenarios.

One such concern is the fragmentation of the traditional workplace, i.e., the distributed workplace, remote work and hoffices. This scenario has been sharply illuminated and speeded up as an adaption to the Covid-19 pandemic, and it also comprises social dissolution at work. Another trend being looked at is the shift from routine employment to non-routine work and employment relations, a development that also is supported by the tech-takeover of routine jobs. A social dilemma in some windows of opportunities of future work concern the risks and opportunities of vulnerable groups, workers with low education levels, disabilities or other constraints. Will they catch up with the new jobs with higher skill levels and work abilities, when many routine jobs are being abolished in the waves of new technologies? A more profound development is that increasing inequalities seems to be an underlying factor in the scenario. "The concept of unequal distribution of wealth, income, opportunity, gender, race, and access to information underlays many of the scenarios in the grey and supplemental literature." (NIOSH, 2020, p.20).

The NIOSH review comprises a broad landscape of various risks and hazards in the current labour market transformation and future of work. It highlights a mosaic of long-standing and already existing OSH-risks in current jobs, and new risk risks in more technology-driven work systems, where the human-machine interaction is escalating at higher skill levels with robots, cobots and the use of various forms of sensors. In the final conclusions, the authors look into new OSH-risks and hazards in the context of increasing job longevity in times of expanding new technology, Al and automation. Will they be able to embark on the new skill market or forced to leave the labour market after displacement? There is not a yes or no answer to this question. The answer depends on the provision of support service, adaptation of workplaces, and a continuous social dialogue at national and global levels. 


\section{Towards greener and more sustainable jobs in Europe}

The table below is an effort to summarise various perspectives on good work ideas and work improvement programmes, in the context of four dimensions of quality; job quality with good work environment and healthy and safe jobs, employment quality and job security, flexible work organisation and, finally recognising climate and energy aspects. Two other crucial aspects are the role work improvement programmes for precarious jobs, and the role of workers participation, co-determination, and employee friendly models for change. Surrounding factors and determinants on macro level are the pace of labour market transformation, technology disruptions and the creation of new jobs. Covid-19, digitalisation, and the promotion of green and climate friendly jobs will speed up labour market mobility, and job shift for individual workers. Thus, sustainable work also needs to consider and develop sustainable employment systems that can manage the growing numbers of job shifts, career re-orientations and transitions.

The social concern about the jobs of the future is expressed in SDG 8 and in the European Pillar of social rights. In the article Redefining working conditions in Europe, Vendramin and Parent-Thirion (2019) analysed data and values on what constitutes job quality from the employees' point of view. They reflect over ideas and concepts of job quality, flexicurity and sustainable work. The Lisbon strategy launched the vision of more and better jobs, a vision that was distorted during the global financial crisis of 2008. Looking ahead, they argue for the idea of sustainable work. "Recently, the notion of sustainable work seems to have prevailed. It offers a more convincing response to an ageing population, to the desire to increase the proportion of older workers in the labour force, and also to the marked increase in musculoskeletal and psychosocial problems among workers of all ages." (Vendramin \& Parent-Thirion, 2019, p. 274).

By shifting from decent work to sustainable work, they underlined the necessity of finding a good work concept that functions both in our times and in the future. Sustainable work does not only focus on job longevity, but it also stresses the need to consider and concern climate change, new energy systems and the road to green work. Stressing sustainable work in a lifecourse, and not only sustainable jobs, illuminates the crucial role of job transition, career development and the adaption to new work system as well as gender structures and worklife balance. 
Table 1. Overview of work improvement programmes and quality focus with reference to sustainable work and green jobs

\begin{tabular}{|c|c|c|c|c|}
\hline $\begin{array}{l}\text { Work } \\
\text { Improvement } \\
\text { Programme/ } \\
\text { Quality focus }\end{array}$ & $\begin{array}{l}\text { Job quality/ OSH, } \\
\text { Good DCR match }\end{array}$ & $\begin{array}{l}\text { Employment } \\
\text { quality - job } \\
\text { security/working } \\
\text { hours/skills }\end{array}$ & $\begin{array}{l}\text { Flexible work } \\
\text { organisation - } \\
\text { Employee friendly } \\
\text { or firm-friendly }\end{array}$ & $\begin{array}{l}\text { Climate, energy\& } \\
\text { SDGs - low- } \\
\text { carbon/ } \\
\text { transformation }\end{array}$ \\
\hline $\begin{array}{l}\text { Decent jobs: } \\
\text { Healthy \& safe } \\
\text { work conditions } \\
\text { ILO/Global Deal }\end{array}$ & High OSH priority & $\begin{array}{l}\text { Job security, union } \\
\text { rights, freedom of } \\
\text { expression }\end{array}$ & $\begin{array}{l}\text { Inclusive growth, } \\
\text { social inclusive } \\
\text { workplaces }\end{array}$ & $\begin{array}{l}\text { New focus in SDG } \\
\text { perspective }\end{array}$ \\
\hline $\begin{array}{l}\text { Good work 1: } \\
\text { Dignity \& ethics } \\
\text { Gardner et al. } \\
\text { (2001) }\end{array}$ & $\begin{array}{l}\text { Values and deeds: } \\
\text { subjective job } \\
\text { satisfaction }\end{array}$ & - & - & - \\
\hline $\begin{array}{l}\text { Good work 2: } \\
\text { Power balance } \\
\text { Swed. Metal Fed/ } \\
\text { LO Sweden }\end{array}$ & High OSH priority & $\begin{array}{l}\text { Job security, union } \\
\text { rights, freedom of } \\
\text { expression }\end{array}$ & $\begin{array}{l}\text { Social dialogue } \\
\text { and workers' co- } \\
\text { determination }\end{array}$ & $\begin{array}{l}\text { Green Deal } \\
\text { policies not so } \\
\text { visible from start }\end{array}$ \\
\hline $\begin{array}{l}\text { Human } \\
\text { Sustainable work } \\
\text { 1: Life- course } \\
\text { work/Docherty/ } \\
\text { Eurofound }\end{array}$ & $\begin{array}{l}\text { OSH over the life } \\
\text { course/ }\end{array}$ & $\begin{array}{l}\text { Job security and } \\
\text { job shift support } \\
\text { crucial in a life- } \\
\text { course view }\end{array}$ & $\begin{array}{l}\text { New forms of } \\
\text { work, work-life } \\
\text { balance, social } \\
\text { partner dialogue }\end{array}$ & $\begin{array}{l}\text { New synergies of } \\
\text { sustainable work } \\
\text { and the green } \\
\text { deal }\end{array}$ \\
\hline $\begin{array}{l}\text { Ecological } \\
\text { Sustainable work } \\
\text { 2: Green low- } \\
\text { carbon jobs } \\
\text { EU/OECD/ILO }\end{array}$ & $\begin{array}{l}\text { OSH priority for } \\
\text { green jobs in } \\
\text { agriculture, } \\
\text { forestry etc }\end{array}$ & $\begin{array}{l}\text { Job security and } \\
\text { union rights also } \\
\text { part of Global } \\
\text { deal-decent jobs }\end{array}$ & $\begin{array}{l}\text { New workplace } \\
\text { innovations for } \\
\text { low-carbon jobs- } \\
\text { employee involv. }\end{array}$ & $\begin{array}{l}\text { The major future } \\
\text { challenge - Next } \\
\text { Generation EU/ } \\
\text { Global Deal }\end{array}$ \\
\hline $\begin{array}{l}\text { Workplace } \\
\text { innovations 1: } \\
\text { Dialogues for } \\
\text { development } \\
\text { EUWIN }\end{array}$ & $\begin{array}{l}\text { High OSH-priority } \\
\text { and job quality }\end{array}$ & $\begin{array}{l}\text { Flexible } \\
\text { employment } \\
\text { relations }\end{array}$ & $\begin{array}{l}\text { Strong focus on } \\
\text { employee driven } \\
\text { WP innovations - } \\
\text { strong links with } \\
\text { industry }\end{array}$ & $\begin{array}{l}\text { Workplace } \\
\text { innovations } \\
\text { crucial to manage } \\
\text { green deal }\end{array}$ \\
\hline $\begin{array}{l}\text { Workplace } \\
\text { innovations 2: } \\
\text { Sustainable } \\
\text { production } \\
\text { systems } \\
\text { EU Green Deal }\end{array}$ & $\begin{array}{l}\text { Resilient energy } \\
\text { system and new } \\
\text { environmentally } \\
\text { friendly material. } \\
\text { OSH one aspect } \\
\text { of many }\end{array}$ & $\begin{array}{l}\text { Sustainable } \\
\text { production } \\
\text { systems - flexible } \\
\text { employment } \\
\text { forms in use }\end{array}$ & $\begin{array}{l}\text { Sustainable and } \\
\text { lean production } \\
\text { models in high } \\
\text { international } \\
\text { competition }\end{array}$ & $\begin{array}{l}\text { Global drive for } \\
\text { green deal and } \\
\text { low-carbon } \\
\text { enterprises - } \\
\text { need for just } \\
\text { transition }\end{array}$ \\
\hline
\end{tabular}

The major challenge is how the vision and concept of sustainable work can be used to create good working conditions in a transformative labour market characterised by job destruction, 
job creation and job retention. Individual working lives cannot not be characterised as a linear development in a context of lifelong employment at the same factory, office or service arena. Life is changing, jobs are disappearing, and others arise, the workers' individual job transitions can sometimes be explained in the form of a free choice, but more often caused by social, economic, technological determinants. A societal vision and model of sustainable work from comprehensive school to senior or post-work positions, presupposes a lifelong learning system integrating youth education, adult education and vocational education, higher education, and a broad range of staff-development and on-the-job learning (Vendramin \& Parent-Thirion (2019), p. 294):

«Sustainable work is a desirable horizon for Europe, insofar as it is likely to underlie a multidimensional approach to quality of work that will take into account working individuals as a whole, with their characteristics, their constraints and their trajectories. The ILO could also choose this direction, which is already reflected in the many points raised during the national dialogues on the future of work (ILO, 2017). Moreover, since the concept of sustainable work initially brought together two issues: that is to say, sustainable development and working systems, it could probably be used to combine the priorities of sustainable development and decent work. »

To sum up: sustainable work requires sustainable education and lifelong learning, i.e., less "what is sustainable work" and more of "what makes work sustainable". And in the context of the new demography with ageing and migration as driving forces, lifelong learning might also be transformed into long life learning. So sustainable work can be a desirable horizon, not only for Europe, but for quality of work in a global sense.

\section{References}

Abrahamsson, K. (2017) Reflections on working life research in Sweden. Institutional transformation, current policies and new networks. EUWIN Bulletin 2/2017.

Alasoini, T., Ramstad, E.\& Totterdill, P. (2017) National and Regional Policies to Promote and Sustain Workplace Innovation. In Oeij,P., Rus,D., Pot ,F. (eds. )(2017) Workplace Innovation. Theory, Research and Practice. Cham: Springer.

Albelda, R., Bell-Pasht, A., Konstantinidis, C. (2020) Gender and Precarious Work in the United States: Evidence from the Contingent Work Supplement 1995-2017. Review of Radical Political Economics, 52 (3), pp. 542-563.

Allvin, M., Aronsson, G., Hagström, T., Johansson, G., \& Lundberg, U. (2011) Work without Boundaries. Psychological Perspectives on the New Working Life. Chichester: Wiley-Blackwell.

Antonovsky, A. (1996) The sense of coherence - An historical and future perspective (1996) Israel Journal of Medical Sciences, 32 (3-4), pp. 170-178.

Arntz, M., Gregory, T. \& Zierahn, U. (2016) The Risk of Automation for Jobs in OECD Countries: A Comparative Analysis, OECD Social, Employment and Migration Working. Papers, No. 189, Paris: OECD Publishing. 
Axelsson, J., Karlsson, J.Ch., \& Skorstad, E. (2019) Collective mobilization in changing conditions: worker collectivity in a turbulent age. Basingstoke: Palgrave Macmillan,

Bazillier, R., Boboc, C., Calavrezo, O. (2016) Measuring employment vulnerability in Europe. International Labour Review, 155 (2), pp. 265-280.

Bergman, A., Karlsson J.C. \& Axelsson, J. (2010) Truth claims and explanatory claims - An ontological typology of future studies. Futures 42: $857-865$

Biggs, J. (2015) All day long. A portrait of Britain at work. London: Serpent's Tail.

Bouwhuis, S., Geuskens, G.A., Boot, C.R.L., Van Der Beek, A.J., Bongers, P.M. (2019) Health differences between multiple and single job holders in precarious employment in the Netherlands: A cross-sectional study among Dutch workers PLOS ONE, 14 (9).

Braverman, H. (1974) Labor and Monopoly Capital. The Degradation of Work in the Twentieth Century. New York and London: Monthly Review Press.

Cazes, S., A. Hijzen \& A. Saint-Martin (2015), Measuring and Assessing Job Quality: The OECD Job Quality Framework", OECD Social, Employment and Migration Working Papers, No. 174, OECD Publishing, Paris.

Conen, W. \& Schippers, J. (eds.) (2019) Self-Employment as Precarious Work: A European Perspective. Cheltenham: Edward Elgar Publishing.

Docherty, P., Kira, M. \& Rami Shani (2009) Creating Sustainable Work Systems. Developing Social Sustainability. 2nd ed. London: Routledge.

EU (2011) A Sustainable Europe for a Better World: A European Union Strategy for Sustainable Development. EU Commission's proposal to the Gothenburg European Council.

EU (2017) European Pillar of Social Rights. EU Publication Office.

EU-OSHA (2018) Foresight on new and emerging occupational safety and health risks associated with digitalisation by 2025 European Risk Observatory Report. Bilbao.

Eurofound (2012) Sustainable work and the ageing workforce: A report based on the fifth European Working Conditions Survey, Publications Office of the European Union, Luxembourg.

Eurofound (2012) Trends in job quality in Europe, Publications Office of the European Union, Luxembourg.

Eurofound (2014) Foundation Seminar Series 2014. Sustainable work through the life-course. Background paper. Dublin.

Eurofound (2015a) Sustainable work over the life course: Concept paper, Publications Office of the European Union, Luxembourg

Eurofound (2015b) New forms of employment, Publications Office of the European Union, Luxembourg.

Eurofound (2016) Sustainable work throughout the life course: National policies and strategies, Publications Office of the European Union, Luxembourg.

Eurofound (2017) Exploring self-employment in the European Union, Publications Office of the European Union, Luxembourg.

Eurofound (2018) Living and working in Europe 2017, Publications Office of the European Union, Luxembourg.

Eurofound (2019) Sustainable work over the life course: Concept paper. Dublin: Eurofound.

Eurofound and ILO (2019) Working conditions in a global perspective, Publications Office of the European Union, Luxembourg, and International Labour Organization, Geneva.

Eurostat (2018) Labour Force Survey (LFS) ad-hoc module 2017 on the self-employed persons ASSESSMENT REPORT 2018 edition. Statistical Reports Eurostat. Luxembourg: EU Publication office.

European Council (2006) Renewed EU Sustainable Development Strategy as adopted by the European Council on 15/16 June 2006. Document No:10917/06

European Parliament (2009) Indicators of job quality in the European Union. Directorate general for internal policies policy department a: economic and scientific policy employment and social affairs 
FAS (2009) Sustainable work - a challenge in times of economic crises. Conference in connection with the Swedish EU Presidency, Stockholm October 2009. Conference report.

Felstead, A., Gallie, D.\& Green, F. (2015) Unequal Britain at work. Oxford: Oxford University Press.

Fischer, K.\& Zink, K.J. (2012) Defining elements of sustainable work systems - a system-oriented approach. Work 41: 3900-3905.

Frey, C. B. \& Osborne, M. A. (2013) The future of employment: Ho susceptible are jobs to computerisation? Oxford: Oxford Martin School, Oxford University.

Green, F. (2006) Demanding Work: The Paradox of Job Quality in the Affluent Economy. Oxford: Princeton University Press.

Hira-Friesen, P. (2018) Immigrants and Precarious Work in Canada: Trends, 2006-2012. Journal of International Migration and Integration, 19 (1), pp. 35-57.

Holzer, H., Lane, J, Rosenblum, D.\& Anderson, F. (2011). Where Are All the Good Jobs Going? What National and Local Job Quality and Dynamics Mean for U.S. Workers. New York: Russel Sage Foundation.

Hvid, H. S., \& Lund, H. L. (2002). Sustainable work: concepts and elements of practice. Journal for Transdisciplinary Environmental Studies, 1(2), $20 \mathrm{~s}$.

Hvid, H.\& Falkum, E. (eds.) (2018). Work and Wellbeing in the Nordic Countries. Critical perspectives on the world's best working life. London: Routledge.

Håkansta, C.\& Abrahamsson, K. (eds.) (2008) Workplaces of the Future. Work-in-Net Foresight Seminar held in Stockholm, Sweden, September 2008.

ILO (2013) Sustainable development, decent work and green jobs. Geneva: ILO.

ILO (2019) Work for a brighter future. Global Commission on the future of work. Geneva: ILO.

ILO and OECD (2020) Social dialogue, skills and covid-19. The global deal for decent work and inclusive growth flagship report. Geneva: ILO.

Kalleberg, A.L. (2011) Good jobs, bad jobs: the rise of polarized and precarious employment systems in the United States, 1970s to 2000s. New York: Russel Sage Foundation.

Kalleberg, A.L.\& Vallas, S.P. (2017) Probing precarious work: Theory, research, and politics Research in the Sociology of Work, 31, pp. 1-30.

Karasek, R. (2017) Science and Research. Psychological Value in Work and Political Economy. Foreword to Deii,P., Rus, D., Pot, F. (eds.) (2017) Workplace Innovation. Theory, Research and Practice. Cham: Springer.

Kira, M, \& Eijnatten, F.M. van (2009). Socially sustainable work organizations: A chaordic systems approach. Systems Research and Behavioral Science, 25 (6), 743-756

Kira, M., \& Eijnatten, F.M. van (2013). Socially sustainable work organizations: A debate. Systems Research \& Behavioral Science, 30 (4), 506-509.

Lewchuk, W. Precarious jobs: Where are they, and how do they affect well-being? (2017) Economic and Labour Relations Review, 28 (3), pp. 402-419.

Lorenz, E., and Potter, J. (2019), "Workplace organisation and innovation in small and medium-sized enterprises", OECD SME and Entrepreneurship Papers, No. 17, OECD Publishing Paris.

Lozano, M., Rentería, E. (2019) Work in Transition: Labour Market Life Expectancy and Years Spent in Precarious Employment in Spain 1986-2016 Social Indicators Research, 145 (1), pp. 185-200.

NIOSH (2020) Potential Scenarios and Hazards in the Work of the Future: A Systematic Review of the PeerReviewed and Gray Literatures. Schulte, et al. Annals of Work Exposures and Health, 2020, 1-31

OECD (2014) "How good is your job? Measuring and assessing job quality", Chapter 3, OECD Employment Outlook 2014, OECD Publishing, Paris.

OECD (2016) How good is your job? Measuring and assessing job quality. http://www.oecd.org/sdd/labourstats/Job-quality-OECD.pdf. Downloaded 2021-01-01. 
Ojala, S., Pyöriä, P. Precarious work and the risk of receiving a disability pension (2019) Scandinavian Journal of Public Health, 47 (3), pp. 293-300.

Oeij, P \& Dondt, S. (2017) Theoretical Approaches Supporting Workplace Innovation. Pages 63-78 in Oeii,P., Rus,D., Pot ,F. (eds. )(2017) Workplace Innovation. Theory, Research and Practice. Cham: Springer.

Oeij,P., Rus, D., Pot, F. (eds.) (2017). Workplace Innovation. Theory, Research and Practice. Cham: Springer.

Oeij, P.R. A. (et al.) Implementing Workplace Innovation Across Europe: Why, How and What? Pages 149-169. I Oeii,,P., Rus,D., Pot ,F. (eds. )(2017) Workplace Innovation. Theory, Research and Practice. Springer

Parent-Thirion, A., Vermeylen, G., Wilken, M., Biletta, I.\& Pot, F.D. Towards the High Road of Workplace Innovation in Europe? An Illustration of the Usefulness of the Dataset of the European Working Conditions Survey. In Deii,P., Rus,D., Pot ,F. (eds. )(2017). Workplace Innovation. Theory, Research and Practice. Cham: Springer

Perry, J.A., Berlingieri, A., Mirchandani, K. (2019) Precarious work, harassment, and the erosion of employment standards. Qualitative Research in Organizations and Management: An International Journal, 15 (3), pp. 331-348.

Pot, F. D., Rus, D.\& Oeij, P.R.A Introduction: The Need to Uncover the Field of Workplace Innovation. Pages 1-8 in Oeij,P., Rus,D., Pot ,F. (eds. )(2017) Workplace Innovation. Theory, Research and Practice. Cham: Springer.

Rose, H.\& Henning, C. (2018) The good life beyond growth: new perspectives. London: Routledge.

Servoz, M. (2019) The future of work? Work of the future! On how artificial intelligence, robotics and automation are transforming jobs and the economy in Europe. Al report. European Commission.

Standing, G. (2011) The precariat. The new dangerous class. New York: Bloomsbury Academic.

Sustainable work in Horizon 2020 (2014) Research Agenda for Sustainable Work as a Resource for Health, Innovation and Growth in Horizon 2020 reflections from an international workshop, February 2014. Lund university

Swedish Agency for Work Environment Expertise (2020) Work environment of the future - trends, digitalization, and employment forms: three systematic reviews. Gävle: Sawee.

Swedish Metal Workers Federation. Kongress (1985) Det goda arbetet (Good work report): huvudrapport från programkommittén om industriarbetets värde och villkor antaget av Svenska metallindustriarbetareförbundets kongress 1-7 september 1985. Stockholm.

Terkel, S. (1997) Working: people talk about what they do all day and how they feel about what they do. New York: New Press.

Theorell, T. (2007) Psychosocial factors in research on work conditions and health in Sweden. Scand J Work Environ Health, vol 33, suppl 1. Pp 20-26.

Theorell, T., \& Karasek, R. A. (1996) Current issues relating to psychosocial job strain and cardiovascular disease research. Journal of Occupational Health Psychology, 1(1), 9-26.

Van Aerden, K., Gadeyne, S., Vanroelen, C. (2017) Is any job better than no job at all? Studying the relations between employment types, unemployment, and subjective health in Belgium (2017) Archives of Public Health, 75 (1), art. no. 55,

Van Horn, C.E., Heidkamp, M. Older workers, precarious jobs, and unemployment: Challenges and policy recommendations (2019) Generations, 43 (3), pp. 21-28.

Vendramin, P. \& Parent-Thirion, A. (2019) Redefining Working Conditions in Europe. In: International Development Policy., Vol. The ILO @ 100, no.11, p. 273-294

Warhurst, C., Carré, F., Findlay, P. Tilly, C. (2012) Are bad jobs inevitable? trends, determinants and responses to job quality in the twenty-first century. New York: Palgrave.

Warhurst, C., Mathieu, C.\& Wright, S. (2017) Workplace Innovation and the Quality of Working Life in an Age of Uberisation. in Oeij,P., Rus,D., Pot ,F. (eds. )(2017) Workplace Innovation. Theory, Research and Practice. Cham: Springer. 
Wegman, D.H.\& Hogstedt, C. (2007) Status report on Swedish work environment research—history, context and international evaluation. Scandinavian Journal of Work Environment \& Health. 33 suppl 1:1-53.

Wenger, E. (1998) Communities of practice: learning, meaning, and identity. Cambridge: Cambridge University Press.

Work-in-net, March 11-12, 2010, The Grand Societal Challenge: sustainable European work to withstand global economic change and crisis. Berlin Declaration WIN-report.

World Economic Forum (2016) The future of jobs. Employment, skills and workforce strategy for the fourth industrial revolution. Geneva: World Economic Forum.

UN (1988) Our Common Future. Report of the World Commission on Environment and Development. New York: United Nation.

Zink, K.J. (2014) Designing sustainable work systems: The need for a systems approach. Applied Ergonomics 45 (2014) 126-132.

\section{About the author}

Kenneth Abrahamsson is a Swedish policy analyst and researcher in the field of work, education and learning. He is presently adjunct professor in human work science, Luleå university of technology and associate professor (docent), Department of Education, University of Stockholm. He has substantial experience as research administrator at various governmental agencies and research funders. He is now a senior consultant and is a member of the Swedish platform for sustainable work in Horizon 2020 and Horizon Europe. 